\title{
Synthesis of Silver (I) Complexes of Iminoalkyl Functionalised $N$-Heterocyclic Carbenes
}

\author{
Neil A. Williams, ${ }^{1,2}$ Mahboub Merzouk, ${ }^{1,2}$ and Peter B. Hitchcock ${ }^{1,2}$ \\ ${ }^{1}$ School of Pharmacy and Chemistry, Faculty of Science, Kingston University, Penrhyn Road, Kingston upon Thames, \\ Surrey KT1 2EE, UK \\ ${ }^{2}$ Department of Chemistry and Biochemistry, University of Sussex, Falmer, Brighton BN1 9QJ, UK
}

Correspondence should be addressed to Neil A. Williams, n.a.williams@kingston.ac.uk

Received 7 January 2010; Accepted 27 March 2010

Academic Editor: W. T. Wong

Copyright ( $) 2010$ Neil A. Williams et al. This is an open access article distributed under the Creative Commons Attribution License, which permits unrestricted use, distribution, and reproduction in any medium, provided the original work is properly cited.

A range of silver iminoalkyl imidazol-2-ylidene complexes have been isolated in good yield (50\%-85\%) and characterised by ${ }^{1} \mathrm{H}$ and ${ }^{13} \mathrm{C}$ NMR spectroscopy. A single crystal X-ray diffraction structure determination of 1-\{2-(benzylhydrylidene-amino)ethyl\}-3-benzyl imidazol-2-ylidene silver bromide indicated monodentate coordination of the ligand.

\section{Introduction}

$N$-heterocyclic carbenes such as imidazol-2-ylidenes have been established as an important class of ligands for transition metals. They typically have strong $\sigma$-donor properties but poor $\pi$-acceptor character and have been widely employed as alternative to phosphine ligands to stabilise transition metal complexes. Imidazol-2-ylidene ligands are conveniently prepared from the deprotonation of imidazolium salts. The use of $\mathrm{Ag}_{2} \mathrm{O}$ to deprotonate imidazolium salts, developed by Lin and coworkers [1] has been widely employed as it gives silver imidazol-2-ylidene complexes that are effective carbene transfer agents and are much more stable than the free carbene [2]. The method is particularly useful when the imidazolium salt contains a base sensitive functional group. A diverse range of transition metal imidazol-2-ylidene complexes have been prepared from silver imidazol-2-ylidene complexes [3, 4].

Metal carbene complexes have been widely employed to catalyse Heck reactions, cross-coupling (such as SuzukiMiyaura coupling) [5], and alkene metathesis reactions [6]. More recently, chiral mixed-donor ligands such as containing an $\mathrm{N}$-heterocyclic carbene donor group have been reported to achieve high enantioselectivity in allylic alkylation [7], hydrogenation [8], and conjugate addition $[9,10]$. In these cases the ligand is chelated to the metal via the imine and car- bene donor groups. Previously, we have reported the synthesis of chiral iminoalkyl imidazolium salts and the generation of palladium imidazol-2-ylidene catalysts via deprotonation with silver oxide and carbene transfer to palladium [11]. In the latter work, the silver intermediates were not isolated or characterised. Here we report the isolation and characterisation of a range of silver iminoalkyl imidazol-2-ylidene complexes. These are of interest as they may be used as chiral catalysts for silver catalysed enantioselective reactions [12].

\section{Experimental}

The single crystal X-ray diffraction data were recorded on a Nonius CCD Kappa diffractometer (graphite-monochromated Mo K $\alpha$ radiation, $\lambda=0.71073 \AA$ ). Data were processed using program package WinGX, absorption correction MULTISCAN. Refinement was by using SHELXL97. Crystallographic data of 2a has been deposited with Cambridge Crystallographic Data centre, Deposition no. CCDC 726775. These data can be obtained free of charge from The Cambridge Crystallographic Data Centre via http://www.ccdc.cam.ac.uk/data_request/cif.

2.1. Preparation 1-\{2-(benzylhydrylidene-amino)-ethyl $\}$-3ben-zylimidazol-2-ylidene of Silver (I) Bromide (2a). Silver oxide (I) $(0.45 \mathrm{~g}, 1.93 \mathrm{mmol})$ was added to a solution of imidazolium salt $(\mathbf{1 a})(1.50 \mathrm{~g}, 3.36 \mathrm{mmol})$ in dichloromethane 
TABle 1: Synthesis of benzylhydrylideneaminoalkyl imidazol-2ylidene silver complexes $\mathbf{2 a - 2 h}$.

\begin{tabular}{llll}
\hline & $\mathrm{R}^{1}$ & $\mathrm{R}^{2}$ & Product yield \\
\hline $\mathbf{1 a}$ & $\mathrm{H}$ & $\mathrm{Bn}$ & 2a $79 \%$ \\
$\mathbf{1 b}$ & $\mathrm{Bn}$ & $\mathrm{Bn}$ & $\mathbf{2 b} 50 \%$ \\
$\mathbf{1 c}$ & $\mathrm{Me}$ & $\mathrm{Bn}$ & $\mathbf{2 c} 84 \%$ \\
$\mathbf{1 d}$ & ${ }^{\mathrm{i}} \mathrm{Bu}$ & $\mathrm{Bn}$ & $\mathbf{2 d} 68 \%$ \\
$\mathbf{1 e}$ & $\mathrm{H}$ & $\mathrm{Ph}$ & $\mathbf{2 e} 78 \%$ \\
$\mathbf{1 f}$ & $\mathrm{Bn}$ & $\mathrm{Ph}$ & $\mathbf{2 f} 66 \%$ \\
$\mathbf{1 g}$ & $\mathrm{Me}$ & $\mathrm{Ph}$ & $\mathbf{2 g} 91 \%$ \\
$\mathbf{1 h}$ & ${ }^{\mathrm{i}} \mathrm{Bu}$ & $\mathrm{Ph}$ & $\mathbf{2 h} 60 \%$ \\
\hline
\end{tabular}

(100 mL) in the presence $4 \AA$ activated molecular sieves ( $4 \mathrm{~g})$. The reaction mixture was protected from light and was refluxed for 2 days. The mixture was filtered through a layer of celite. The solvent was then removed under reduced pressure to give $2 \mathbf{a}$ as a white solid (1.47 g, 79\%); mp 157.5$162.1^{\circ} \mathrm{C} ; v_{(\mathrm{C}=\mathrm{N})}: 1623 \mathrm{~cm}^{-1} ;{ }^{1} \mathrm{H}$ NMR (DMSO-d $6,400 \mathrm{MHz}$ ) $\delta_{\mathrm{H}} 3.63(\mathrm{t}, 2 \mathrm{H}, J=5.3 \mathrm{~Hz}), 4.39(\mathrm{t}, 2 \mathrm{H}, J=5.3 \mathrm{~Hz}), 5.26$ (s, 2H), 6.79-6.86 (m, 2H), 7.15-7.60 (m, 15H,); ${ }^{13} \mathrm{C}$ NMR $\left(\mathrm{DMSO}_{\mathrm{d}}, 100 \mathrm{MHz}\right) \delta_{\mathrm{C}} 52.153 .9$ (2C), 121.8, 122.4, 127.0, $127.3,127.9,128.5,130.1,135.6,137.1,138.6,168.7$ (1C, $\mathrm{C}=\mathrm{N}$ ), 179.8 (1C, C-Ag); Anal. found: C 54.26\%, H 4.00\%, $\mathrm{N} 7.64 \%$; $\left(\mathrm{C}_{25} \mathrm{H}_{23} \mathrm{~N}_{3} \mathrm{AgBr}\right.$ requires C $54.27 \%, \mathrm{H} 4.19 \%, \mathrm{~N}$ 7.60\%).

Complexes $\mathbf{2} \mathbf{b}-\mathbf{2} \mathbf{h}$ and $\mathbf{3} \mathbf{a}-\mathbf{3} \mathbf{b}$ were prepared according to the same procedure.

2.2. Compound $2 \boldsymbol{b}$. White solid; yield: $0.21 \mathrm{~g}, 50 \% ;{ }^{1} \mathrm{H}$ NMR $\left(\mathrm{DMSO}_{-} \mathrm{d}_{6}, 400 \mathrm{MHz}\right) \sigma_{\mathrm{H}} 2.89(\mathrm{dd}, 1 \mathrm{H}, J=8.8 \mathrm{~Hz}, J=$ $13.0 \mathrm{~Hz}), 2.95(\mathrm{dd}, 1 \mathrm{H}, J=4.4 \mathrm{~Hz}, J=13.0 \mathrm{~Hz}), 3.60-3.75$ $(\mathrm{m}, 1 \mathrm{H}),, 4.31(\mathrm{dd}, 1 \mathrm{H}, J=2.6 \mathrm{~Hz}, J=13.3 \mathrm{~Hz}), 4.49(\mathrm{dd}$, $1 \mathrm{H}, J=9.9 \mathrm{~Hz}, J=13.3 \mathrm{~Hz}), 5.05-5.25(\mathrm{~m}, 2 \mathrm{H}), 5.66(\mathrm{~s}, 1 \mathrm{H}$,$) ,$ $5.68(\mathrm{~s}, 1 \mathrm{H}),, 6.90-7.52(\mathrm{~m}, 20 \mathrm{H}) ;{ }^{13} \mathrm{C}$ NMR (DMSO-d $\mathrm{d}_{6}$, $100 \mathrm{MHz}) \delta_{\mathrm{C}} 49.4,54.2,56.4,64.8,121.7,122.9,126.2,126.4$, $127.4,127.6,127.8,128.0,128.09,128.13,128.6,129.7$ (2C), 130.2, 132.6, 136.9, 137.9, 138.4, $168.4(\mathrm{C}=\mathrm{N}), 179.8$ (C-Ag); Anal. found: C 59.98\%, H 4.18\%, N 6.31\% $\left(\mathrm{C}_{32} \mathrm{H}_{29} \mathrm{~N}_{3} \mathrm{AgBr}\right.$ requires C 59.74\%, H 4.54\%, N 6.53\%).

2.3. Compound $2 c$. White solid; yield: $0.47 \mathrm{~g}, 84 \%$; $\mathrm{mp} 85.5-$ $88.2^{\circ} \mathrm{C} ;{ }^{1} \mathrm{H}$ NMR (DMSO-d $\left.6,400 \mathrm{MHz}, 35^{\circ} \mathrm{C}\right) \delta_{\mathrm{H}} 1.12(\mathrm{~d}$, $3 \mathrm{H}, J=6.6 \mathrm{~Hz}), 3.57-3.69(\mathrm{~m}, 1 \mathrm{H}) 4.17(\mathrm{dd}, 1 \mathrm{H}, J=2.9 \mathrm{~Hz}$, $J=13.2 \mathrm{~Hz}), 4.34(\mathrm{dd}, J=9.5 \mathrm{~Hz}, J=13.2 \mathrm{~Hz}), 5.05-5.40$ (m, 2H), $6.54(\mathrm{~s}, 1 \mathrm{H}), 6.56(\mathrm{~s}, 1 \mathrm{H}),, 7.50-7.60(\mathrm{~m}, 15 \mathrm{H},) ;{ }^{13} \mathrm{C}$ NMR (DMSO-d $\left.6,100 \mathrm{MHz}, 35^{\circ} \mathrm{C}\right) \delta_{\mathrm{C}} 19.2,54.1,57.5,58.4$, $121.8,122.7,126.7,127.4,127.9,128.0,128.1128 .46,128.53$, 130.2 , 135.6, 137.1, 138.4, 167.4 (C=N), 179.6 (C-Ag).

2.4. Compound $2 \boldsymbol{d}$. White solid; yield: $0.25 \mathrm{~g}, 68 \% ;{ }^{1} \mathrm{H}$ NMR $\left(\mathrm{DMSO}_{-} \mathrm{d}_{6}, 400 \mathrm{MHz}\right) \delta_{\mathrm{H}} 0.63(\mathrm{~d}, 3 \mathrm{H}, J=6.4 \mathrm{~Hz}), 0.76(\mathrm{~d}$, $3 \mathrm{H}, J=6.4 \mathrm{~Hz}), 1.37-1.59(\mathrm{~m}, 3 \mathrm{H}), 3.55-3.68(\mathrm{~m}, 1 \mathrm{H}), 4.22-$ $4.50(\mathrm{~m}, 2 \mathrm{H}), 5.07-5.27(\mathrm{~m}, 2 \mathrm{H}), 6.39(\mathrm{~s}, 2 \mathrm{H}), 7.09-7.55(\mathrm{~m}$, $15 \mathrm{H}) ;{ }^{13} \mathrm{C} \mathrm{NMR}\left(\mathrm{DMSO}_{6}, 100 \mathrm{MHz}\right.$ ) $\delta_{\mathrm{C}} 22.6,23.0,23.9$, 42.8, 54.1, 56.4, 60.8, 121.7, 122.9, 126.9 (2C), 130.0 (2C),
$127.4,127.9,128.0,128.1,128.2,128.5,135.5,136.8,138.6$, $167.7(\mathrm{C}=\mathrm{N}), 179.9$ (C-Ag).

2.5. Compound $2 \boldsymbol{e}$. White solid; yield: $0.34 \mathrm{~g}, 78 \% ;{ }^{1} \mathrm{H}$ NMR $\left(\mathrm{DMSO}_{-} \mathrm{d}_{6}, 400 \mathrm{MHz}\right) \delta_{\mathrm{H}} 3.67(\mathrm{t}, 4 \mathrm{H}, J=5.4 \mathrm{~Hz}), 4.45(\mathrm{t}$, $4 \mathrm{H}, J=5.4 \mathrm{~Hz}), 6.29$ (s, 2H), 7.10-7.53 (m, 15H); ${ }^{13} \mathrm{C} \mathrm{NMR}$ $\left(\mathrm{DMSO}_{-} \mathrm{d}_{6}, 100 \mathrm{MHz}\right) \delta_{\mathrm{C}} 52.5,53.9,121.8,123.4,123.5$, $126.9,127.9,128.0,128.39,128.43,128.6129 .4,129.5,130.1$, 135.6 (2C), $138.6(2 \mathrm{C}), 139.6(2 \mathrm{C}), 170.1(\mathrm{C}=\mathrm{N}), 168.9(\mathrm{C}-$ $\mathrm{Ag})$.

2.6. Compound $2 f$. White solid; yield: $0.16 \mathrm{~g}, 66 \% ;{ }^{1} \mathrm{H}$ NMR $\left(\mathrm{DMSO}_{\mathrm{d}}, 400 \mathrm{MHz}\right) \delta_{\mathrm{H}} 3.20-3.35(\mathrm{~m}, 2 \mathrm{H}), 3.60-3.80(\mathrm{~m}$, $1 \mathrm{H}), 4.10-4.25(\mathrm{~m}, 1 \mathrm{H}), 4.30-4.45(\mathrm{~m}, 1 \mathrm{H}), 6.69(\mathrm{~s}, 2 \mathrm{H})$, 7.10-7.90 (m, 20H); ${ }^{13} \mathrm{C}$ NMR (DMSO-d, $\left.100 \mathrm{MHz}\right) \delta_{\mathrm{C}}$ 57.6 (2C), 58.4, 121.6, 123.5 (3C), 126.6, 127.9, 128.0, 128.3, $128.5,129.6,129.9,130.1,135.7$ (2C), 138.5, 139.7, 167.4 $(\mathrm{C}=\mathrm{N})$, not vis. (1C, C-Ag).

2.7. Compound 2g. White solid 0.11 g, 91\%; mp 85.0$87.4^{\circ} \mathrm{C}$; ${ }^{1} \mathrm{H}$ NMR (DMSO-d $\left.6,400 \mathrm{MHz}\right) \delta_{\mathrm{H}} 1.20(\mathrm{~d}, 3 \mathrm{H}, \mathrm{J}=$ $5.9 \mathrm{~Hz}), 3.68-3.85(\mathrm{~m}, 1 \mathrm{H}), 4.17-4.33(\mathrm{~m}, 1 \mathrm{H}), 4.40(\mathrm{dd}, 1 \mathrm{H}$, $J=9.3 \mathrm{~Hz}, J=13.4 \mathrm{~Hz}), 6.75(\mathrm{~s}, 2 \mathrm{H}), 7.25-7.62(\mathrm{~m}, 14 \mathrm{H})$, $7.83(\mathrm{~s}, 1 \mathrm{H}) ;{ }^{13} \mathrm{C}$ NMR (DMSO-d $\left.6,100 \mathrm{MHz}\right) \delta_{\mathrm{C}} 19.3$ 57.7, 58.5, 121.9, 123.5, 123.6, 126.6, 128.0, 128.1, 128.6, 129.7, $130.3,135.7,138.5,139.6,168.5$, not vis. (1C, C-Ag).

2.8. Compound $2 \boldsymbol{h}$. White solid; yield: $0.071 \mathrm{~g}, 60 \%$; $\mathrm{mp}$ 68.2-70.5 ${ }^{\circ}$; ${ }^{1} \mathrm{H}$ NMR $\left(\mathrm{CDCl}_{3}, 400 \mathrm{MHz}\right) \delta_{\mathrm{H}} 0.70(\mathrm{~d}, 3 \mathrm{H}, J$ $=6.4 \mathrm{~Hz}), 0.82(\mathrm{~d}, 3 \mathrm{H}, J=6.4 \mathrm{~Hz}), 1.40-1.63(\mathrm{~m}, 3 \mathrm{H}), 3.73-$ $3.87(\mathrm{~m}, 1 \mathrm{H}), 4.22-4.45(\mathrm{~m}, 2 \mathrm{H}),, 6.57(\mathrm{~s}, 1 \mathrm{H}), 6.59(\mathrm{~s}, 1 \mathrm{H})$, $7.10-7.65(\mathrm{~m}, 15 \mathrm{H}) ;{ }^{13} \mathrm{C} \mathrm{NMR}\left(\mathrm{CDCl}_{3}, 100 \mathrm{MHz}\right) \delta_{\mathrm{C}} 22.8$, 23.2, 24.6, 43.1, 57.7, 61.2, 121.0, 123.2, 123.6 (2C), 126.9 (2C), 128.1 (2C), 128.38 (2C), 128.41 (2C,), 128.7, 128.9, 129.8 (2C), 130.3, 135.9, 138.9, 139.6, $168.8(\mathrm{C}=\mathrm{N}), 180.7$ (C-Ag).

2.9. Compound 3a. White solid (0.27g, 85\%); ${ }^{1} \mathrm{H}$ NMR $\left(\mathrm{CDCl}_{3}, 400 \mathrm{MHz}\right) \delta_{\mathrm{H}} 0.88(\mathrm{~d}, 3 \mathrm{H}, J=6.6 \mathrm{~Hz}), 0.93(\mathrm{~d}, 3 \mathrm{H}, J$ $=6.6 \mathrm{~Hz}), 1.35-1.73(\mathrm{~m}, 3 \mathrm{H}),, 3.63-3.72(\mathrm{~m}, 1 \mathrm{H}), 4.22(\mathrm{dd}$, $1 \mathrm{H}, J=9.2 \mathrm{~Hz}, J=13.6 \mathrm{~Hz}), 4.34(\mathrm{dd}, 1 \mathrm{H}, J=3.7 \mathrm{~Hz}, J=$ $13.6 \mathrm{~Hz}), 5.20(\mathrm{~d}, 2 \mathrm{H}, J=9.2 \mathrm{~Hz}), 7.07-7.44(\mathrm{~m}, 9 \mathrm{H}), 7.54-$ $7.62(\mathrm{~m}, 2 \mathrm{H}), 8.04(\mathrm{~s}, 1 \mathrm{H}),, 10.19(\mathrm{~s}, 1 \mathrm{H}) ;{ }^{13} \mathrm{C} \mathrm{NMR}\left(\mathrm{CDCl}_{3}\right.$, $100 \mathrm{MHz}) \delta_{\mathrm{C}} 21.6,23.5,24.4,42.1,55.6,57.2,70.1,120.4$, $122.9,128.2$ (2C), 128.5 (2C), 128.6 (2C), 129.1, 129.1 (2C), $131.2,135.5,137.4,161.6\left(1 \mathrm{C}, \mathrm{N}=\mathrm{CH}-\mathrm{C}_{6} \mathrm{H}_{5}\right), 181.2(1 \mathrm{C}, \mathrm{C}-$ $\mathrm{Ag})$.

2.10. Compound 3b. White solid (0.064 g, 77\%); ${ }^{1} \mathrm{H}$ NMR $\left(\mathrm{CD}_{2} \mathrm{Cl}_{2}, 400 \mathrm{MHz}\right) \delta_{\mathrm{H}} 0.65(\mathrm{~d}, 3 \mathrm{H}, J=6.3 \mathrm{~Hz}), 0.72(\mathrm{~d}, 3 \mathrm{H}$, $J=6.3 \mathrm{~Hz}), 1.37-1.57(\mathrm{~m}, 3 \mathrm{H}), 1.96(\mathrm{~s}, 3 \mathrm{H}), 2.12(\mathrm{~s}, 3 \mathrm{H}), 2.20$ (s, 3H), 3.54-3.77 (m, 6H), 3.84-3.94 (m, 1H), $6.81(\mathrm{~s}, 1 \mathrm{H})$, $6.87(\mathrm{~s}, 1 \mathrm{H}), 7.08(\mathrm{~s}, 1 \mathrm{H}), 7.10(\mathrm{~s}, 1 \mathrm{H}), 7.20-7.36(\mathrm{~m}, 3 \mathrm{H})$, 7.37-7.47 (m, 3H), 7.55-7.65 (m, 2H); ${ }^{13} \mathrm{C} \mathrm{NMR}\left(\mathrm{CD}_{2} \mathrm{Cl}_{2}\right.$, $100 \mathrm{MHz}) \delta_{\mathrm{C}} 17.7,17.8,20.8,22.77,22.83,24.8,43.2,50.6$, 51.2, 56.9, 58.9, 127.7 (2C), 128.2 (2C), 128.7 (4C), 129.5 (3C), 130.3 (1C), 135.7, 135.8, 135.9, 136.6, 138.6, 139.3, $167.9(\mathrm{C}=\mathrm{N})$, not vis. (1C, $\mathrm{C}-\mathrm{Ag})$. 
TABLE 2: Crystal data and structure refinement.

\begin{tabular}{|c|c|c|}
\hline & $2 a$ & \\
\hline Empirical formula & C25 H23 Ag Br N3 & \\
\hline Formula weight & 553.24 & \\
\hline Temperature & $173(2) \mathrm{K}$ & \\
\hline Wavelength & $0.71073 \AA$ & \\
\hline Crystal system & Triclinic & \\
\hline Space group & $\mathrm{P} \overline{1}($ No. 2$)$ & \\
\hline \multirow[t]{3}{*}{ Unit cell dimensions } & $a=8.1675(2) \AA$ & $\alpha=92.909(2)^{\circ}$ \\
\hline & $\mathrm{b}=8.6875(3) \AA$ & $\beta=92.682(2)^{\circ}$ \\
\hline & $c=16.5972(6) \AA$ & $\gamma=106.820(2)^{\circ}$ \\
\hline Volume & $1123.49(6) \AA^{3}$ & \\
\hline $\mathrm{Z}$ & 2 & \\
\hline Density (calculated) & $1.64 \mathrm{Mg} / \mathrm{m}^{3}$ & \\
\hline Absorption coefficient & $2.69 \mathrm{~mm}^{-1}$ & \\
\hline $\mathrm{F}(000)$ & 552 & \\
\hline Crystal size & $0.25 \times 0.20 \times 0.10 \mathrm{~mm}^{3}$ & \\
\hline Theta range for data collection & 3.89 to $25.03^{\circ}$ & \\
\hline Index ranges & $-9 \leq h \leq 8,-10 \leq k \leq 10,-19 \leq 1 \leq 19$ & \\
\hline Reflections collected & 16098 & \\
\hline Independent reflections & $3930[\mathrm{R}($ int $)=0.043]$ & \\
\hline Reflections with I > 2sigma(I) & 3495 & \\
\hline Completeness to theta $=25.03^{\circ}$ & $98.9 \%$ & \\
\hline Refinement method & Full-matrix least-squares on $\mathrm{F}^{2}$ & \\
\hline Data/restraints/parameters & $3930 / 0 / 363$ & \\
\hline Goodness-of-fit on $\mathrm{F}^{2}$ & 1.071 & \\
\hline Final $R$ indices $[\mathrm{I}>2 \operatorname{sigma}(\mathrm{I})]$ & $\mathrm{R} 1=0.027, \mathrm{wR} 2=0.063$ & \\
\hline $\mathrm{R}$ indices (all data) & $\mathrm{R} 1=0.033, \mathrm{wR} 2=0.066$ & \\
\hline Largest diff. peak and hole & 0.42 and $-0.53 \mathrm{e} \cdot \AA^{-3}$ & \\
\hline
\end{tabular}

TABLE 3: Selected bond distances and angles for $\mathbf{2 a}$.

\begin{tabular}{lccc}
\hline & Angles $\left(^{\circ}\right)$ & & Distances $(\AA)$ \\
\hline $\mathrm{C}(1)-\mathrm{Ag}-\mathrm{Br}$ & $154.76(8)$ & $\mathrm{Ag}-\mathrm{C}(1)$ & $2.015(3)$ \\
$\mathrm{C}(1)-\mathrm{Ag}-\mathbf{B r}^{\prime}$ & $109.20(7)$ & $\mathrm{Ag}-\mathrm{Br}$ & $2.4969(3)$ \\
$\mathrm{Br}^{\prime} \mathrm{Ag}-\mathbf{B r}^{\prime}$ & $95.823(11)$ & $\mathrm{Ag}-\mathrm{Br}{ }^{\prime}$ & $3.0549(4)$ \\
Ag-Br-Ag' $^{\prime}$ & $84.177(11)$ & $\mathrm{N}(1)-\mathrm{C}(1)$ & $1.353(4)$ \\
$\mathrm{C}(1)-\mathrm{N}(1)-\mathrm{C}(2)$ & $111.1(2)$ & $\mathrm{N}(1)-\mathrm{C}(2)$ & $1.382(4)$ \\
$\mathrm{C}(1)-\mathrm{N}(1)-\mathrm{C}(4)$ & $124.7(2)$ & $\mathrm{N}(1)-\mathrm{C}(4)$ & $1.460(4)$ \\
$\mathrm{C}(2)-\mathrm{N}(1)-\mathrm{C}(4)$ & $124.0(3)$ & $\mathrm{N}(2)-\mathrm{C}(1)$ & $1.350(4)$ \\
$\mathrm{C}(1)-\mathrm{N}(2)-\mathrm{C}(3)$ & $111.0(2)$ & $\mathrm{N}(2)-\mathrm{C}(3)$ & $1.392(4)$ \\
$\mathrm{C}(1)-\mathrm{N}(2)-\mathrm{C}(11)$ & $125.1(2)$ & $\mathrm{N}(2)-\mathrm{C}(11)$ & $1.462(4)$ \\
$\mathrm{N}(2)-\mathrm{C}(1)-\mathrm{Ag}$ & $129.5(2)$ & $\mathrm{N}(3)-\mathrm{C}(13)$ & $1.278(4)$ \\
$\mathrm{N}(1)-\mathrm{C}(1)-\mathrm{Ag}$ & $126.19(19)$ & & \\
\hline
\end{tabular}

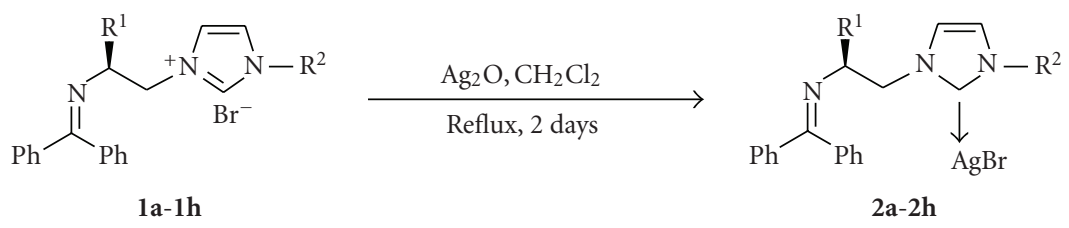

FIgURE 1: Synthesis of benzylhydrylideneaminoalkyl imidazol-2-ylidene silver complexes $\mathbf{2 a - 2 h}$. 
<smiles>Br[C@@H](C[C@H](Cc1ccccc1)N=Cc1ccccc1)C[n+]1ccn(Br)c1</smiles><smiles>CC(C)(C)OCCl</smiles>

(a)<smiles>Br[B-]N1CCN(Cc2ccccc2)C1</smiles>

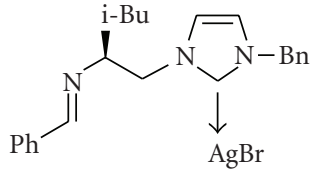

$3 a$

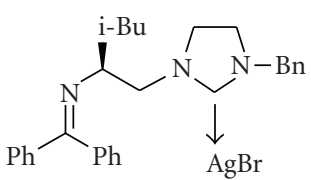

$3 b$

(b)

Figure 2: Synthesis of benzylideneaminoalkyl imidazol-2-ylidene $\mathbf{3 a}$ and imidazolin-2-ylidene silver complexes $\mathbf{3 b .}$

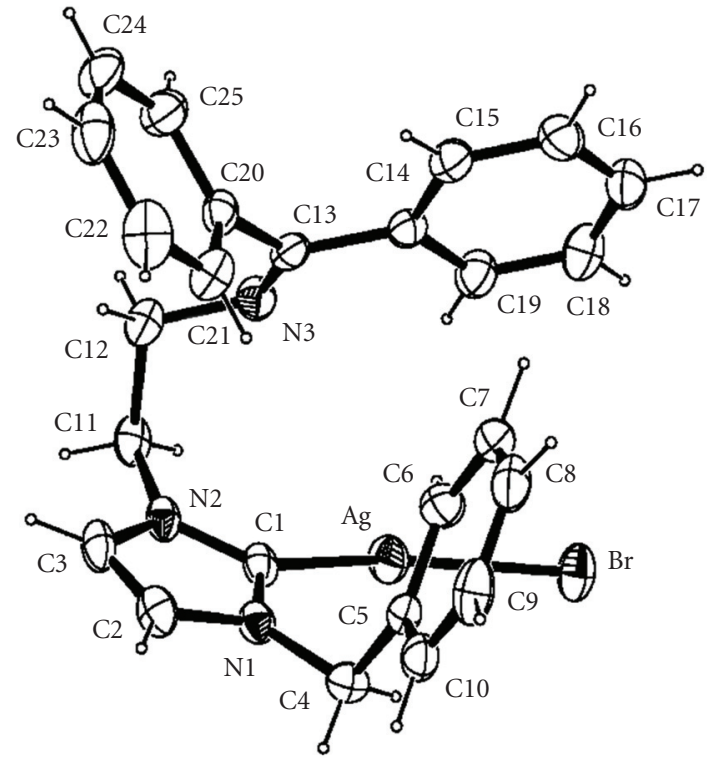

FIGURE 3: X-ray crystal structure of silver carbene complex 2a.

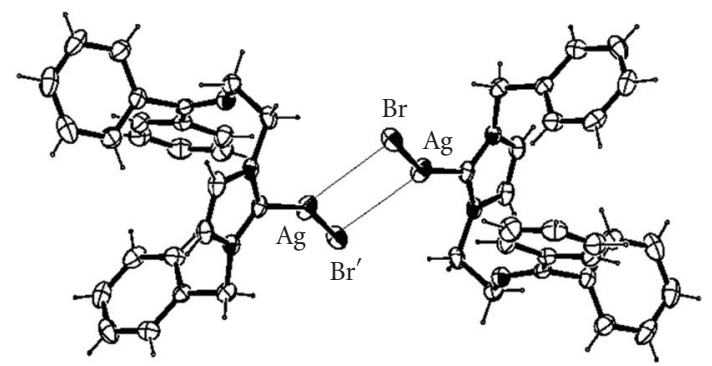

FIGURE 4: X-ray crystal structure of 2 a showing weak interactions between monomers.

\section{Results and Discussion}

The synthesis of iminoalkyl imidazolium salts $\mathbf{1 a - 1 h}$ has been previously reported. The imidazolium salt $\mathbf{1 a}$ was deprotonated by silver (I) oxide in dry $\mathrm{CH}_{2} \mathrm{Cl}_{2}$ under reflux, in the presence of activated $4 \AA$ molecular sieves $[13,14]$. The reaction was carried out in the dark to prevent photodecomposition of the silver complex. After 2 days, the achiral silver imidazol-2-ylidene complex 2 a was obtained in good yield (79\%). The method was subsequently extended to the preparation of chiral silver imidazol-2ylidene complexes $\mathbf{2} \mathbf{b}-\mathbf{2} \mathbf{h}$ from chiral iminoalkyl $N$-benzyl, $N$-phenyl imidazolium bromide salts $\mathbf{1 b}$-1h (Figure 1 ). The yields ranged from $45 \%$ to $91 \%$ (Table 1 ). The steric bulk of the $\mathrm{R}^{1}$ substituent appears to have a significant effect on the yield of the reaction, for $\mathrm{R}^{1}=\mathrm{H}$ or Me yields are in the range $78 \%-91 \%$ whilst for $\mathrm{R}^{1}=\mathrm{Bn},{ }^{\mathrm{i}} \mathrm{Bu}$ they are in the range $50 \%-$ $68 \%$. This is consistent with the observation of Lin et al. that yields of silver complex formation are dependent on steric hindrance around the imidazolium salt [15].

The silver carbene transfer agent (3a) was prepared as the reduced steric bulk of a benzylideneamino-donor group has been linked to improved selectivity in palladium catalysed allylic alkylation [7, 16]. In addition, the imidazolin-2ylidene silver complex (3b) is of interest as the unsaturated imidazolin-2-ylidene is considered a stronger $\sigma$-donor ligand and hence could enable greater electronic differentiation of a coordinated allyl group when $\mathbf{3 b}$ is employed as a carbene transfer agent in palladium catalysed allylic alkylation. This should result in greater enantioselectivity (Figure 2).

The deprotonation of imidazolium salts $\mathbf{1 a - 1 h}$ was evidenced by the disappearance of imidazolium $\mathrm{C}_{1}$ proton singlet in the ${ }^{1} \mathrm{H}$ NMR spectra between 9 and $10 \mathrm{ppm}$. The coordination of the carbene carbon to the $\mathrm{Ag}(\mathrm{I})$ centre was characterised by ${ }^{13} \mathrm{C} \mathrm{NMR} .{ }^{13} \mathrm{C} \mathrm{NMR}$ analysis confirmed conservation of the imine double bond, with the quaternary carbon signals observed between 168.5 and $170.1 \mathrm{ppm}$. The characteristic $\mathrm{C}_{1}$ carbon signals of $\mathbf{2 a -}$ 2h were generally shifted up field from c.a. $136 \mathrm{ppm}$ for imidazolium compounds, to c.a. $180 \mathrm{ppm}$ for the carbene with no measurable coupling with silver. The carbene carbon signals were generally not detected for chiral silver iminoalkyl $N$-phenylimidazol-2-ylidene complexes $\mathbf{2 e - 2 h}$. The lack of $\mathrm{Ag}(\mathrm{I})-{ }^{13} \mathrm{C}$ coupling is indicative of labile nature in silver complexes [17], Danopoulos [13] and Douthwaite [16] reported similar structural and spectroscopic observations 
for chiral silver iminoalkyl $N$-substituted imidazol-2-ylidene complexes. Diastereotopic methyl groups in compounds derived from leucine $(\mathbf{2} \mathbf{d}, \mathbf{2 h})$ gave a rise to doublet of doublets in the ${ }^{1} \mathrm{H}$ NMR spectra.

The deprotonation of $N$-functionalised imidazolium halides and their coordination to $\mathrm{Ag}(\mathrm{I})$ can lead to a variety of structures, including: ion pairs, mononuclear neutral complexes, halide bridged complexes, bridged tetranuclear complexes, or bis carbene complexes. Single crystals of $\mathbf{2 a}$ were grown by slow diffusion of diethyl ether into a saturated equivolume solution of $\mathrm{CH}_{2} \mathrm{Cl}_{2} / \mathrm{Et}_{2} \mathrm{O}$. The single crystal Xray diffraction structure determination indicated compound 2a was a mononuclear neutral complex with monodentate coordination of the imino-alkyl)imidazol-2-ylidene ligand (Table 2, Figure 3). However, there is evidence of weak interactions between monomers across an inversion centre (Figure 4).

X-ray crystallographic data of $2 \mathbf{a}$ indicates that the distance between the imine nitrogen $(\mathrm{N}(3))$ and the $\mathrm{Ag}$ atom $(3.402 \AA)$ is significantly longer than that between the carbene carbon $(\mathrm{C}(1))$ and $\mathrm{Ag}(2.105 \AA$ ) (Table 3$)$. Although the imine nitrogen is directed toward the $\mathrm{Ag}$ atom, the two atoms are too far away to significantly interact. The structure of 2 a with no imine N(3)-Ag coordination, is in agreement with the general trend of silver to form linear and low coordinate complexes [9]. The orientation of the imine moiety away from the metal centre is assumed to be due to steric hindrance.

\section{Conclusion}

A range of silver iminoalkyl imidazole-2-ylidene complexes have been synthesised and characterised. The single crystal $\mathrm{X}$-ray diffraction study of $\mathbf{2 a}$ reveals a neutral mononuclear structure in which the imine donor group is not coordinated to the silver. Further work will be aimed at synthesising palladium iminoalkyl imidazole-2-ylidene complexes using these new compounds as carbene transfer agents.

\section{References}

[1] H. M. J. Wang and I. J. B. Lin, "Facile synthesis of silver(I)-carbene complexes. Useful carbene transfer agents," Organometallics, vol. 17, no. 5, pp. 972-975, 1998.

[2] I. J. B. Lin and C. S. Vasam, "Preparation and application of $\mathrm{N}$-heterocyclic carbene complexes of $\mathrm{Ag}(\mathrm{I})$," Coordination Chemistry Reviews, vol. 251, no. 5-6, pp. 642-670, 2007.

[3] T. Weskamp, V. P. W. Böhm, and W. A. Herrmann, "Nheterocyclic carbenes: state of the art in transition-metalcomplex synthesis," Journal of Organometallic Chemistry, vol. 600, no. 1-2, pp. 12-22, 2000.

[4] J. C. Garrison and W. J. Youngs, "Ag(I) N-heterocyclic carbene complexes: synthesis, structure, and application," Chemical Reviews, vol. 105, no. 11, pp. 3978-4008, 2005.

[5] E. A. B. Kantchev, C. J. O’Brien, and M. G. Organ, "Palladium complexes of $\mathrm{N}$-heterocyclic carbenes as catalysts for crosscoupling reactions - a synthetic chemist's perspective," Angewandte Chemie International Edition, vol. 46, no. 16, pp. 27682813, 2007.
[6] E. Colacino, J. Martinez, and F. Lamaty, "Preparation of NHCruthenium complexes and their catalytic activity in metathesis reaction," Coordination Chemistry Reviews, vol. 251, no. 5-6, pp. 726-764, 2007.

[7] L. G. Bonnet, R. E. Douthwaite, and B. M. Kariuki, "Synthesis of new chiral $\mathrm{N}$-heterocyclic carbene-imine ligands and their application to an asymmetric allylic alkylation reaction," Organometallics, vol. 22, no. 21, pp. 4187-4189, 2003.

[8] M. C. Perry, X. Cui, M. T. Powell, D.-R. Hou, J. H. Reibenspies, and K. Burgess, "Optically active iridium imidazol-2-ylideneoxazoline complexes: preparation and use in asymmetric hydrogenation of arylalkenes," Journal of the American Chemical Society, vol. 125, no. 1, pp. 113-123, 2003.

[9] H. Clavier, L. Coutable, J.-C. Guillemin, and M. Mauduit, "New bidentate alkoxy-NHC ligands for enantioselective copper-catalysed conjugate addition," Tetrahedron Asymmetry, vol. 16, no. 5, pp. 921-924, 2005.

[10] D. Martin, S. Kehrli, M. D’Augustin, H. Clavier, M. Mauduit, and A. Alexakis, "Copper-catalyzed asymmetric conjugate addition of Grignard reagents to trisubstituted enones. Construction of all-carbon quaternary chiral centers," Journal of the American Chemical Society, vol. 128, no. 26, pp. 8416-8417, 2006.

[11] M. Merzouk, T. Moore, and N. A. Williams, "Synthesis of chiral iminoalkyl functionalised $N$-heterocyclic carbenes and their use in asymmetric catalysis," Tetrahedron Letters, vol. 48, no. 50, pp. 8914-8917, 2007.

[12] H. Mandai, K. Mandai, M. L. Snapper, and A. H. Hoveyda, "Three-component Ag-catalyzed enantioselective vinylogous mannich and Aza-Diels-Alder reactions with alkyl-substituted aldehydes," Journal of the American Chemical Society, vol. 130, no. 52, pp. 17961-17969, 2008.

[13] A. A. D. Tulloch, A. A. Danopoulos, S. Winston, S. Kleinhenz, and G. Eastham, "N-functionalised heterocyclic carbcne complexes of silver," Dalton Transactions, no. 24, pp. 4499-4506, 2000.

[14] K. S. Coleman, H. T. Chamberlayne, S. Turberville, M. L. H. Green, and A. R. Cowley, "Silver(I) complex of a new imino $N$-heterocyclic carbene and ligand transfer to palladium(II) and rhodium(I)," Dalton Transactions, no. 14, pp. 2917-2922, 2003.

[15] J. C. Y. Lin, R. T. W. Huang, C. S. Lee, A. Bhattacharyya, W. S. Hwang, and I. J. B. Lin, "Coinage metal $N$-heterocyclic carbene complexes," Chemical Reviews, vol. 109, no. 8, pp. 3561-3598, 2009.

[16] L. G. Bonnet, R. E. Douthwaite, and B. M. Kariuki, "Synthesis of new chiral $N$-heterocyclic carbene-imine ligands and their application to an asymmetric allylic alkylation reaction," Organometallics, vol. 22, no. 21, pp. 4187-4189, 2003.

[17] X. Hu, Y. Tang, P. Gantzel, and K. Meyer, "Silver complexes of a novel tripodal $N$-heterocyclic carbene ligand: evidence for significant metal-carbene $\pi$-interaction," Organometallics, vol. 22, no. 4, pp. 612-614, 2003. 


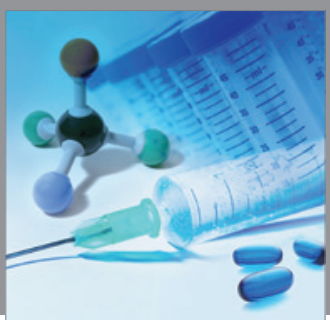

International Journal of

Medicinal Chemistry

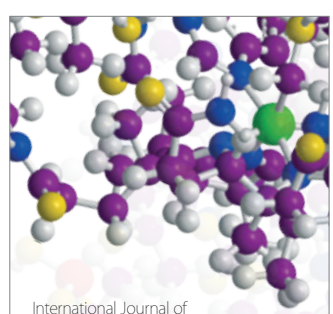

Carbohydrate Chemistry

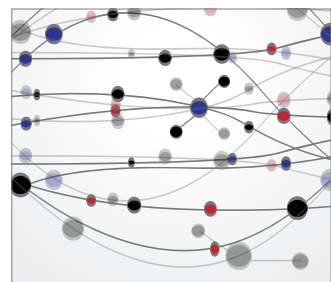

The Scientific World Journal
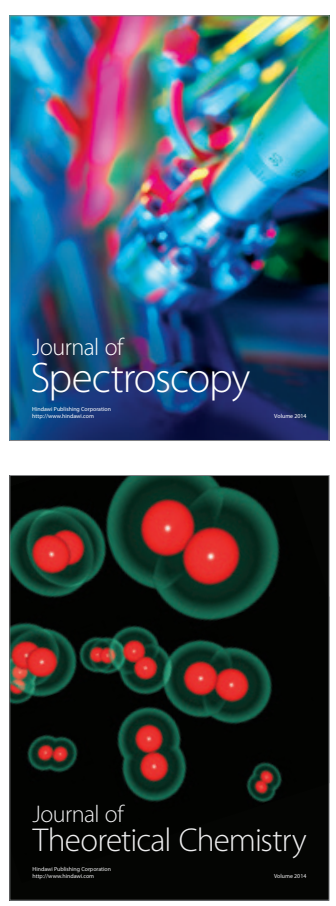
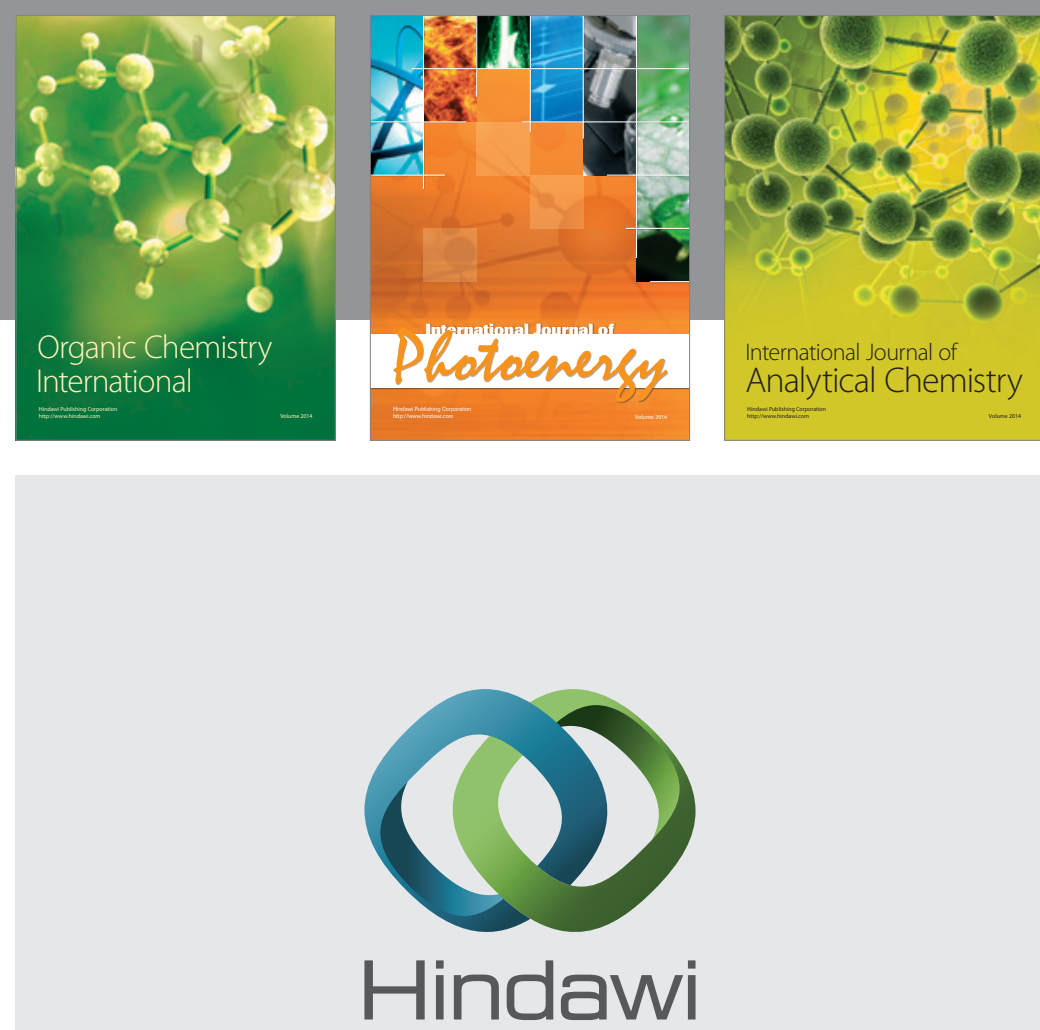

Submit your manuscripts at

http://www.hindawi.com
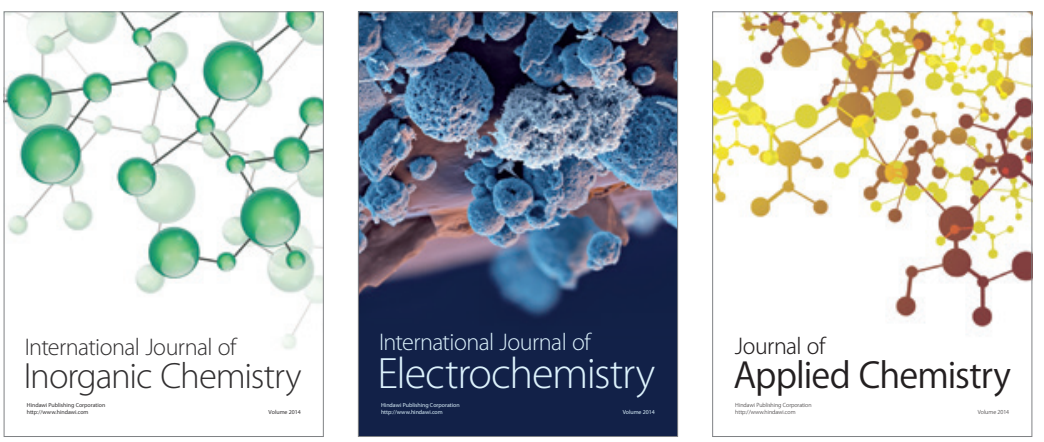

Journal of

Applied Chemistry
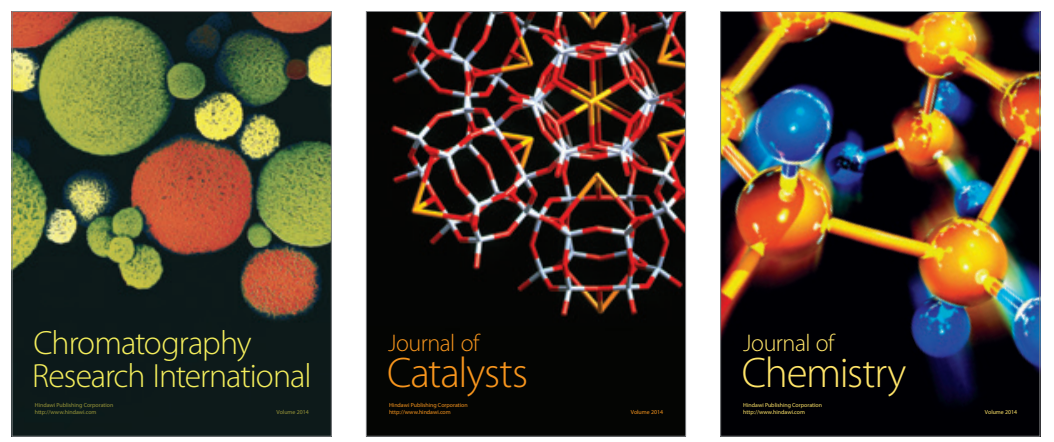
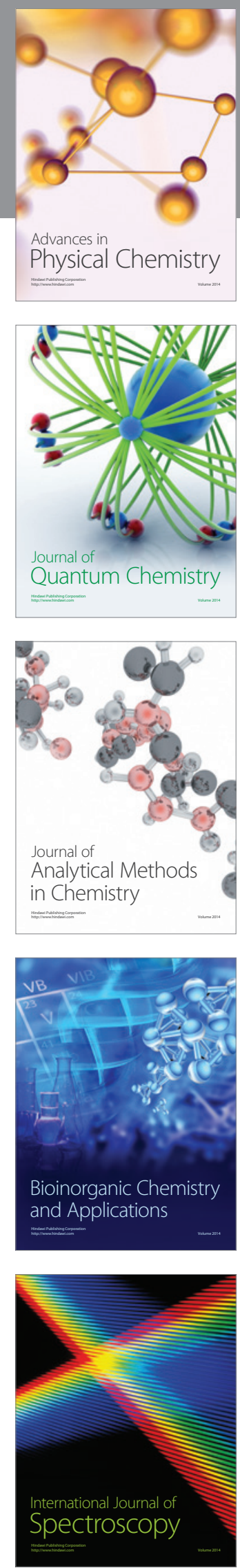